\title{
FEASIBILITY STUDY OF INDUSTRIAL PROJECTS USING SIMOS’ PROCEDURE
}

\author{
Mohamed Marzouk ${ }^{1}$, Omar Amer ${ }^{2}$, Moheeb El-Said ${ }^{3}$ \\ Department of Structural Engineering, Faculty of Engineering, Cairo University, El Gamaa St., Giza, Egypt \\ E-mails: ${ }^{1} m m \_m a r z o u k @ y a h o o . c o m\left(c o r r e s p o n d i n g\right.$ author); ${ }^{2}$ omar.amer@mcg-consult.com; \\ 3elsaid1204@yahoo.com \\ Received 19 Mar. 2011; accepted 07 Jun. 2011
}

\begin{abstract}
Feasibility study is conducted in a stage prior to design, procurement and construction stages in order to determine the viability of project undertaken by an investor. This helps investors to decide whether to proceed with the project or not. Multi-Criteria Decision Making (MCDM) process can be utilized in the feasibility study stage to avoid wrong decisions might cause undesired losses. In industrial projects, wrong decisions might lead to bankruptcy of crucial economic entities. Private investors might have good initiative and the capital to establish economically successful projects but they might either select the inappropriate type of industry that might turn the investment to a failure or might not include some important/crucial considerations into account. This paper presents a key-list of gathered factors that are considered the important factors and affect the selection of industrial projects. Importance, relative importance and weights of these factors are determined using Simos' procedure. The key-list has been applied on five case-studies of industrial projects and a Weighted-Sum Model (WSM) has been selected as a MCDM technique in order to acquire their final preferences, rank them and consequently come-up with the most preferred/suitable alternative to be constructed. Then, a sensitivity analysis has been performed to determine the most critical criterion of the key-list. Additionally, several scenarios have been processed to verify that the most important criterion of the key-list does not necessarily be the most critical criterion. Moreover, the sensitivity analysis also determines the most critical measure of performance assembled from the five casestudies.
\end{abstract}

Keywords: multi-criteria decision making, feasibility study, Simos' procedure, Weighted-Sum Model, sensitivity analysis, ranking techniques, industrial projects.

\section{Introduction}

Multi-Criteria Decision Making has taken massive concern in the research field over the past few decades. This reflects how important this issue is since its early conception. When the number of factors/criteria which affect the decision making process increase, it is then considered multi-criteria decision making process. In industrial projects, wrong decisions might lead to bankruptcy of crucial economic entities as well as bankruptcy of banks and might expand to be rated as crimes, as in Waste of Public Money. Feasibility study should be well prepared prior to any further procedures. There exist a type of private investors that might have the good initiative and the capital to construct economically successful projects but they might either select the inappropriate type of industry that might turn the investment to a failure or might not include some important/crucial considerations into account (Amer 2010). This paper targets private investors who have investment intentions in Egypt and who search for the most suitable/appropriate industrial project to be constructed in Egypt's industrial zones (e.g.: New Port Said East Port, $10^{\text {th }}$ of Ramadan City, etc.) in order to invest their capitals. This paper proposes a methodology for selecting industrial projects.
In construction industry, value engineering is one fertile discipline for the application of Multi-Criteria Decision Making techniques thanks to the several exchanges of alternatives' combinations till the decision maker reaches a satisfactory solution. A generic tool for value engineering has been proposed using superiority and inferiority ranking technique (SIR). The tool has been developed using VBA ${ }^{\circledR}$ (Marzouk 2008a). The SIR-VE input includes: i) selected criteria; ii) alternatives to be ranked; iii) ranking procedure (either SAW or TOPSIS) and iv) criteria weights (either to be defined or estimated). For all selected criteria, it is required to define name of criterion, preferred limit (the main objective either to maximized or minimized the criterion) and selected generalized criterion. The same technique has been used in a well-known MCDM practice which is contractor selection (Marzouk 2008b). It has been also used in selecting concrete pumps (Tam et al. 2004). The case study is based on a 34-story building located in a $1,800 \mathrm{~m}^{2}$ construction site in Hong Kong. It comprises ten alternatives in form of types of pumps (supplied to site by contractor) and eleven different criteria. A brief comparison - based on five characteristics - between five MCDM techniques (AHP, ELECTRE III, Fuzzy Logic, PROMETHEE and SIR) is presented. The advantages of using superiority and inferiority ranking technique in equipment selection 
are also presented. Selection of concrete pumps is also introduced using ELECTRE III (Ulubeyli, Kazaz 2009). They also made survey about the previous papers concerning the selection of construction equipment, the type of equipment to be selected and the selection method.

A generic tool has been developed for contractor selection that is capable to (Marzouk, Moselhi 2003): i) evaluation bid proposals (i.e, contractor selection); and/or ii) assisting the contractors themselves in estimating the markup in their bidding. In other words, unlike the models developed for similar purposes, the proposed model provides a decision support environment for the two functions; that is, estimating markup and evaluating bid. Dissimilar to the previous multi-criteria decision making methods used in the papers introduced in this section, the model in this paper utilizes the multi-attribute utility theory in addition to the analytic hierarchy process and makes use of their advantages. Bid markup estimation was developed using utility-theory by Dozzi et al. (1996). The research is conducting, considering the following procedure: 1) create a short-list that contains the most important factors on which the decision of the private investor in solving the problem defined earlier will be based; 2) develop a multi-criteria decision making approach that can rank the alternatives of the possible industrial projects; 3 ) apply sensitivity analysis to identify the most critical criterion and the most critical measure of performance.

\section{Factors identification}

An extensive search has taken place for the factors that might affect selection of the most appropriate type of industry. A preliminary list has been gathered from literature (Changshan 2007; Roussat et al. 2009; UNDP 2010) and interviews with the experts in the field. Six interviews have been conducted; in addition to, other several unstructured interviews but with no direct impact on the preliminary list of factors. The list contains 27 factors that belong to three clusters that are Economic, SocioEconomic and Environmental as listed in Table 1. After considering the 27 -factors list, a process of acquiring the importance of factors has been performed. This has taken place by preparing a questionnaire survey. The main purpose of the questionnaire survey is to get the importance of the gathered factors. The factors were listed and given a scale from one to five. Degree one is the least important degree and degree five is the most important degree. The respondents evaluated each factor as if they are private investors. In other words, the questionnaire was evaluated from private investors' point of view, in order to make their decision on selecting the type of industry in which they can invest their money. Screening the gathered factors is an important phase. This is an important step in the track of reaching a reliable short-list/key list that contains the most important factors on which the private investor can rely upon in reaching the most appropriate industrial project to be constructed in Egypt's industrial zones. Low important factors have been eliminated. They are those factors those factors whose frequency cells that appear in Table 1 verifies the equation $[(1+2+(0.5 * 3)) \leq$
$((0.5 * 3)+4+5)]$. The frequency cells reflect the numbers of votes for each level of importance (from 1 to 5 ) related to each factor. The numbers of votes have been gathered from the questionnaire feedback. Table 1 lists the result of the screening process (Importance frequency). It should be noted that four factors have been eliminated from the 27-factors list forming more reliable list of 23 factors. The eliminated factors are Males to Females Ratio, Females Employment, Illiteracy and Ecological Impact. The first three factors belong to the SocioEconomic cluster, while the fourth factor belongs to the Environmental cluster.

Table 1. Frequency of importance for gathered factors

\begin{tabular}{|c|c|c|c|c|c|c|}
\hline \multirow{2}{*}{$\begin{array}{l}\dot{\bar{v}} \\
\stackrel{\tilde{D}}{\Xi}\end{array}$} & \multirow{2}{*}{ Factor } & \multicolumn{5}{|c|}{ Frequency } \\
\hline & & 1 & 2 & 3 & 4 & 5 \\
\hline \multirow{3}{*}{ 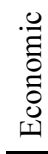 } & 1) Time & 0 & 0 & 9 & 11 & 8 \\
\hline & 2) Cost & 0 & 1 & 4 & 9 & 14 \\
\hline & 3) Reward & 0 & 1 & 1 & 1 & 25 \\
\hline \multirow{17}{*}{ 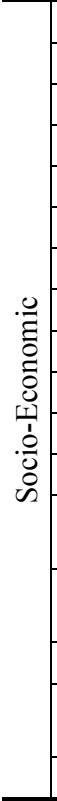 } & 4) Employment & 0 & 2 & 15 & 10 & 1 \\
\hline & 5) Income Share Per Capita & 0 & 6 & 10 & 9 & 3 \\
\hline & 6) Growth Rate Ratio & 0 & 4 & 7 & 11 & 6 \\
\hline & 7) Males to Females Ratio & 7 & 10 & 6 & 4 & 1 \\
\hline & 8) Females Employment & 7 & 11 & 5 & 5 & 0 \\
\hline & 9) Illiteracy & 3 & 6 & 10 & 7 & 2 \\
\hline & 10) Skilled Labors & 0 & 0 & 5 & 9 & 14 \\
\hline & 11) Age of Working Power & 1 & 4 & 9 & 12 & 2 \\
\hline & 12) Land Parcel Inventory & 1 & 2 & 6 & 13 & 6 \\
\hline & 13) Crime Location Data & 1 & 4 & 4 & 10 & 9 \\
\hline & 14) Public Health Info & 3 & 0 & 6 & 10 & 9 \\
\hline & 15) Population & 3 & 3 & 12 & 8 & 2 \\
\hline & $\begin{array}{l}\text { 16) Gross Domestic Product } \\
\text { (GDP) }\end{array}$ & 2 & 2 & 6 & 14 & 4 \\
\hline & $\begin{array}{l}\text { 17) Electrical Power Con- } \\
\text { sumption }\end{array}$ & 0 & 2 & 4 & 11 & 11 \\
\hline & 18) Housing Price & 0 & 5 & 5 & 12 & 6 \\
\hline & $\begin{array}{l}\text { 19) Human Development } \\
\text { Index (HDI) }\end{array}$ & 1 & 4 & 13 & 7 & 3 \\
\hline & 20) Local Public Acceptance & 1 & 3 & 9 & 8 & 7 \\
\hline \multirow{7}{*}{ 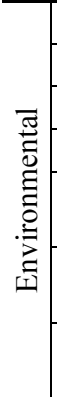 } & 21) Pollution & 1 & 0 & 5 & 14 & 8 \\
\hline & 22) Global Warming & 2 & 5 & 12 & 6 & 3 \\
\hline & 23) Noise Impact & 1 & 5 & 8 & 11 & 3 \\
\hline & 24) Ecological Impact & 1 & 9 & 11 & 5 & 2 \\
\hline & $\begin{array}{l}\text { 25) Landscape \& Visual } \\
\text { Impact }\end{array}$ & 0 & 6 & 14 & 5 & 3 \\
\hline & $\begin{array}{l}\text { 26) Waste Management } \\
\text { Impact }\end{array}$ & 2 & 2 & 4 & 16 & 4 \\
\hline & $\begin{array}{l}\text { 27) Hazardous Chemicals } \\
\text { Control }\end{array}$ & 0 & 2 & 5 & 10 & 11 \\
\hline
\end{tabular}

\section{Analysis of relative importance}

After having the importance of the gathered factors and eliminating the low important factors, the relative importance for the remaining factors is obtained. Relative importance couldn't have been acquired in an earlier stage since it would have been a complex action to get the importance and the relative importance in one exercise. Also, questionnaire feedback could have been possibly 
inaccurate. The relative importance is essential for assigning the weight of each factor. Weights allocation of factors is consequently essential since it will be integrated with a ranking technique. A procedure called Simos' procedure has been followed to acquire both the relative importance and the weights of factors (Figueira, Roy 2002).

A questionnaire has been prepared to get the relative importance of the factors. In the second questionnaire, aside assigning the relative importance of the factors, it was also required from the participants to assign the relative importance of the three main clusters/families for which all the factors belong. All responses have been compiled to reflect all assigned relative importance. This resultant has been developed by taking the average of each criterion in the questionnaire to calculate the total average relative importance. According to the average column, a sorting process has been performed based on the algorithm of Simos. The result of the sorting process has been added to an additional and final column. The process of getting a resultant to the received relative importance is shown in Table 2.

It is important to clarify why Weighted-Sum Model (WSM) is preferred to be used than other ranking techniques like Analytic Hierarchy Process (AHP). For example, using AHP necessitates formulating a number of pairwise matrixes (decision matrixes) for every single cluster/family of the available factors; in addition to, the main clusters themselves. That means that Table 2 is going to be breakdown into four different matrixes, one of which is going to be a $14 \times 14$ matrix. This case will be confusing and also incredibly time consuming for experts/participants who are going to fill up the questionnaire. Additionally, after performing the consistency ratio check on the questionnaire feedback, the probability of finding inconsistent answers is expected to be high. Accordingly, this most likely is going take the whole process in a loop which might not be useful to the research process. On the other hand, in this case WSM is used along with Simos' procedure making the questionnaire process (through Table 2) way easier to perform and - to great extent - assuring reliable feedback as well. Another reason of WSM preference is that potential audience of this research might be private investors and/or developers. Presenting a smooth procedure which performs the same job might be useful for better understanding to the study.

Before proceeding in further steps, an investigation of the factors has been performed. It has been found that factors which are constant among all alternatives of the decision making process (industrial projects) could have been eliminated since their effect will obviously be constant as well. Factors which are constant among all alternatives are those which are related to the location of

Table 2. Second questionnaire responses

\begin{tabular}{|c|c|c|c|c|c|c|c|c|}
\hline \multirow{2}{*}{ Cluster } & \multirow{2}{*}{ Factor } & \multicolumn{5}{|c|}{ Relative Weighting } & \multirow{2}{*}{ Average } & \multirow{2}{*}{$\begin{array}{l}\text { Simos' } \\
\text { Rank }\end{array}$} \\
\hline & & Q1 & Q2 & Q3 & Q4 & Q5 & & \\
\hline \multirow{3}{*}{ Economic } & 1) Time & 1 & 1 & 1 & 2 & 2 & 1.4 & 1 \\
\hline & 2) Cost & 1 & 2 & 2 & 1 & 1 & 1.4 & 1 \\
\hline & 3) Reward & 2 & 3 & 3 & 3 & 3 & 2.8 & 2 \\
\hline \multirow{14}{*}{ Socio-Economic } & 4) Employment & 3 & 4 & 10 & 8 & 2 & 5.4 & 7 \\
\hline & 5) Income Share Per Capita & 2 & 4 & 3 & 2 & 1 & 2.4 & 2 \\
\hline & 6) Growth Rate Ratio & 2 & 5 & 1 & 1 & 1 & 2 & 1 \\
\hline & 7) Skilled Labors & 4 & 3 & 12 & 9 & 4 & 6.4 & 8 \\
\hline & 8) Age of Working Power & 3 & 3 & 5 & 10 & 4 & 5 & 6 \\
\hline & 9) Land Parcel Inventory & 4 & 6 & 11 & 11 & 5 & 7.4 & 11 \\
\hline & 10) Crime Location Data & 1 & 2 & 2 & 3 & 2 & 2 & 1 \\
\hline & 11) Public Health Info & 3 & 3 & 7 & 4 & 3 & 4 & 5 \\
\hline & 12) Population & 3 & 2 & 3 & 3 & 3 & 2.8 & 3 \\
\hline & 13) Gross Domestic Product (GDP) & 2 & 2 & 6 & 5 & 1 & 3.2 & 4 \\
\hline & 14) Electrical Power Consumption & 4 & 5 & 8 & 12 & 5 & 6.8 & 9 \\
\hline & 15) Housing Price & 4 & 3 & 9 & 13 & 3 & 6.4 & 8 \\
\hline & 16) Human Development Index (HDI) & 2 & 1 & 4 & 6 & 1 & 2.8 & 3 \\
\hline & 17) Local Public Acceptance & 4 & 5 & 13 & 7 & 6 & 7 & 10 \\
\hline \multirow{6}{*}{ Environmental } & 18) Pollution & 2 & 5 & 6 & 4 & 4 & 4.2 & 5 \\
\hline & 19) Global Warming & 1 & 1 & 1 & 1 & 1 & 1 & 1 \\
\hline & 20) Noise Impact & 2 & 2 & 5 & 3 & 2 & 2.8 & 2 \\
\hline & 21) Landscape \& Visual Impact & 3 & 3 & 4 & 2 & 3 & 3 & 2 \\
\hline & 22) Waste Management Impact & 2 & 4 & 2 & 5 & 6 & 3.8 & 3 \\
\hline & 23) Hazardous Chemicals Control & 2 & 5 & 3 & 6 & 5 & 4.2 & 4 \\
\hline \multirow{3}{*}{ Main Clusters } & Economic & 2 & 3 & 3 & 3 & 3 & 2.8 & 2 \\
\hline & Socio-Economic & 1 & 1 & 2 & 2 & 1 & 1.4 & 1 \\
\hline & Environmental & 1 & 2 & 1 & 1 & 2 & 1.4 & 1 \\
\hline
\end{tabular}


projects' initiation. These factors include: 1) Growth Rate Ratio; 2) Age of Working Power; 3) Crime Location Data; 4) Population; 5) Gross Domestic Product (GDP); 6) Housing Price; 7) Human Development Index (HDI). At the same time, frequent trials concerning collection of records and data related to the gathered factors were taking place. Numerous visits were organized to visit several authorities including: Egyptian Industrial Development Authority, Egyptian Environmental Affairs Agency and Egyptian Social Fund for Development. The purpose of the visit is to identify significant factors. It has been found that some factors do not have either any records or having outdated measures. These factors are: 1) Income share per capita; 2) Global Warming; 3) Noise Impact; 4) Landscape and Visual Impact; 5) Hazardous Chemicals Control. By eliminating the stated above factors from the second questionnaire responses resultant, eleven sound and practical factors remained for further processes as listed in Table 3.
After getting the relative importance and performing the final screening, the list of factors now appear to be consistent/practical and measurable (i.e., ready for further processes). A short-list (key list) containing the most important factors on which the decision of the private investor in searching for the most appropriate industrial project to be constructed in Egypt will be based. In continuation to the paper objectives, the relative importance acquired is used in order to get the weights for the factors. Getting weights of factors is the second part in Simos' procedure as listed in Table 4. Since there is more than one family/cluster, the calculated weights still have to be converted from local weights within each cluster to global weights among all factors of all clusters. Except the local weights for the main cluster, they are already considered global too. Table 5 lists that the local normalized weights that are previously calculated which are multiplied by the weight of each relative cluster forming global weights.

Table 3. Modified list of factors

\begin{tabular}{|c|c|c|c|c|c|c|c|c|}
\hline \multirow{2}{*}{ Cluster } & \multirow{2}{*}{ Factor } & \multicolumn{5}{|c|}{ Relative Weighting } & \multirow{2}{*}{ Average } & \multirow{2}{*}{$\begin{array}{r}\text { Simos' } \\
\text { Rank }\end{array}$} \\
\hline & & Q1 & Q2 & Q3 & Q4 & Q5 & & \\
\hline \multirow{3}{*}{ Economic } & 1) Time & 1 & 1 & 1 & 2 & 2 & 1.4 & 1 \\
\hline & 2) Cost & 1 & 2 & 2 & 1 & 1 & 1.4 & 1 \\
\hline & 3) Reward & 2 & 3 & 3 & 3 & 3 & 2.8 & 2 \\
\hline \multirow{6}{*}{ Socio-Economic } & 4) Employment & 3 & 4 & 10 & 8 & 2 & 5.4 & 2 \\
\hline & 5) Skilled Labors & 4 & 3 & 12 & 9 & 4 & 6.4 & 3 \\
\hline & 6) Land Parcel Inventory & 4 & 6 & 11 & 11 & 5 & 7.4 & 6 \\
\hline & 7) Public Health Info & 3 & 3 & 7 & 4 & 3 & 4 & 1 \\
\hline & 8) Electrical Power Consumption & 4 & 5 & 8 & 12 & 5 & 6.8 & 4 \\
\hline & 9) Local Public Acceptance & 4 & 5 & 13 & 7 & 6 & 7 & 5 \\
\hline \multirow{2}{*}{ Environmental } & 10) Pollution & 2 & 5 & 6 & 4 & 4 & 4.2 & 2 \\
\hline & 11) Waste Management Impact & 2 & 4 & 2 & 5 & 6 & 3.8 & 1 \\
\hline \multirow{3}{*}{ Main Clusters } & Economic & 2 & 3 & 3 & 3 & 3 & 2.8 & 2 \\
\hline & Socio-Economic & 1 & 1 & 2 & 2 & 1 & 1.4 & 1 \\
\hline & Environmental & 1 & 2 & 1 & 1 & 2 & 1.4 & 1 \\
\hline
\end{tabular}

Table 4. Determining relative weights of factors/criteria

\begin{tabular}{|c|c|c|c|c|c|c|}
\hline Factor & No. of Cards & \multicolumn{2}{|c|}{ Positions } & Non-Normalized weights & Normalized weights & Total \\
\hline$\{$ Time, Cost $\}$ & 2 & 1 & 1 & 1 & 25 & 50 \\
\hline$\{$ Reward $\}$ & 1 & \multicolumn{2}{|c|}{2} & 2 & 50 & 50 \\
\hline Sum & 3 & \multicolumn{2}{|c|}{4} & & & 100 \\
\hline$\{$ Public Health Info $\}$ & 1 & \multicolumn{2}{|c|}{1} & 1 & 5 & 5 \\
\hline$\{$ Employment\} & 1 & \multicolumn{2}{|c|}{2} & 2 & 10 & 10 \\
\hline$\{$ Skilled Labors $\}$ & 1 & \multicolumn{2}{|c|}{3} & 3 & 14 & 14 \\
\hline$\{$ Electrical Power Consumption $\}$ & 1 & \multicolumn{2}{|c|}{4} & 4 & 19 & 19 \\
\hline$\{$ Local Public Acceptance\} & 1 & \multicolumn{2}{|c|}{5} & 5 & 24 & 24 \\
\hline$\{$ Land Parcel Inventory $\}$ & 1 & \multicolumn{2}{|c|}{6} & 6 & 29 & 29 \\
\hline Sum & 6 & \multicolumn{2}{|c|}{21} & & & 100 \\
\hline$\{$ Waste Management Impact\} & 1 & \multicolumn{2}{|c|}{1} & 1 & 33 & 33 \\
\hline$\{$ Pollution\} & 1 & \multicolumn{2}{|c|}{2} & 2 & 67 & 67 \\
\hline Sum & 3 & \multicolumn{2}{|c|}{4} & & & 100 \\
\hline$\{$ Socio-Economic, Environmental\} & 2 & 1 & 1 & 1 & 25 & 50 \\
\hline$\{$ Economic $\}$ & 1 & \multicolumn{2}{|c|}{2} & 2 & 50 & 50 \\
\hline Sum & 3 & \multicolumn{2}{|c|}{4} & & & 100 \\
\hline
\end{tabular}


Table 5. Global weights of factors

\begin{tabular}{l|c|c|c}
\hline \multicolumn{1}{c|}{ Factors } & $\begin{array}{c}\text { Relative } \\
\text { Weights }\end{array}$ & $\begin{array}{c}\text { Relative } \\
\text { Weights of } \\
\text { Clusters }\end{array}$ & $\begin{array}{c}\text { Global } \\
\text { Weights }\end{array}$ \\
\hline Time & 0.250 & 0.5 & 0.125 \\
\hline Cost & 0.250 & 0.5 & 0.125 \\
\hline Reward & 0.500 & 0.5 & 0.250 \\
\hline Public Health Info & 0.048 & 0.25 & 0.012 \\
\hline Employment & 0.095 & 0.25 & 0.024 \\
\hline Skilled Labors & 0.143 & 0.25 & 0.036 \\
\hline $\begin{array}{l}\text { Electrical Power } \\
\text { Consumption }\end{array}$ & 0.190 & 0.25 & 0.048 \\
\hline $\begin{array}{l}\text { Local Public } \\
\text { Acceptance }\end{array}$ & 0.238 & 0.25 & 0.060 \\
\hline Land Parcel Inventory & 0.286 & 0.25 & 0.071 \\
\hline $\begin{array}{l}\text { Waste Management } \\
\text { Impact }\end{array}$ & 0.333 & 0.25 & 0.083 \\
\hline Pollution & 0.667 & 0.25 & 0.167 \\
\hline
\end{tabular}

\section{Acquiring values of factors}

Several visits have been carried out to industrial projects/factories of different types in order to acquire real values/measures to the list of factors. There were five factories and this activity is considered five different case studies, representing industrial projects. The details of factories are:

1. Factory 1 produces nylon bags of different sizes (project is related to petrochemical industry);

2. Factory 2 produces PVC pipes (project is also related to petrochemical industry);

3. Factory 3 is a huge mechanical workshop/ warehouse;

4. Factory 4 produces $\&$ galvanizes steel towers of mobile phone networks;

5. Factory 5 produces steel towers of mobile phone networks without galvanization.

Table 6 shows more information about the criteria and factors for five factories. Public Health Info, Local Public Acceptance, Pollution and Waste Management Impact criteria are based on grades from 1 to 10 . By returning to the definitions of these criteria, it can be easily understood that these criteria are descriptive; conse- quently, they have been given grades to make the numerical evaluation possible.

\section{Ranking of alternatives}

The matrix depicted in Table 7 contains a column named Types of Industries. It is essential to identify which factory belongs to which type of industry and develop the Types of Industries column. The Public Health Info and Pollution criteria are recommended to be kept to the minimum. This means that as long as the given grade decreases to grade one, the alternative becomes more preferred. On the contrary, Local Public Acceptance and Waste Management Impact criteria are recommended to be increased. This means that as long as the given grade increases to grade ten, the alternative becomes more preferred. It can be noted that the entire column of criterion Local Public Acceptance does not show any change in its values. All alternatives have a value of 10 for this criterion. It is a coincidence in this scenario that all alternatives had the same value towards the Local Public Acceptance criterion; otherwise, it could have been eliminated in an earlier stage with other criteria which could have been potentially constant among all alternatives as in the criteria related to project location.

After reviewing some important issues in the decision matrix, ranking of alternatives determination process should begin. This is carried out using Weighted-Sum Model (WSM) method (Fishburn 1967). Developing the decision matrix with real measures of the selected criteria against the five different alternatives (case study projects) was the first step.

Secondly, all values were normalized to add up to one (Table 8). In other words, normalization can be either processed in relative to the largest value among specified set of values (column) or processed in relative to the summation of a specified set of values (column). What has been applied here is that the normalization is processed in accordance to the latter option. It can be also noticed that the raw which was carrying the units of criteria has been substituted by the weights of each criterion. This is because the normalized figures are now dimension-less; moreover, these weights will be used for the next step.

Table 6. Exposition of criteria

\begin{tabular}{c|l|c|c|c}
\hline Criterion & \multicolumn{1}{|c|}{ Name } & Weight & Objective & Units \\
\hline$C_{1}$ & Time & 0.125 & Minimize & Months \\
\hline$C_{2}$ & Cost & 0.125 & Minimize & EGP \\
\hline$C_{3}$ & Reward & 0.25 & Maximize & EGP/Year \\
\hline$C_{4}$ & Employment & 0.02381 & Minimize & Number \\
\hline$C_{5}$ & Skill Labor & 0.03571 & Minimize & M \\
\hline$C_{6}$ & Land Parcel Inventory & 0.07143 & Minimize & m \\
\hline$C_{7}$ & Public Health Info & 0.0119 & Minimize & $1-10$ \\
\hline$C_{8}$ & Electrical Power Consumption & 0.04762 & Minimize & Mwatt/hr \\
\hline$C_{9}$ & Local Public Acceptance & 0.05952 & Maximize & $1-10$ \\
\hline$C_{10}$ & Pollution & 0.16667 & Minimize & $1-10$ \\
\hline$C_{11}$ & Waste Management Impact & 0.08333 & Maximize & $1-10$ \\
\hline
\end{tabular}




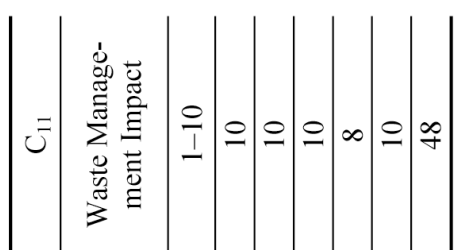

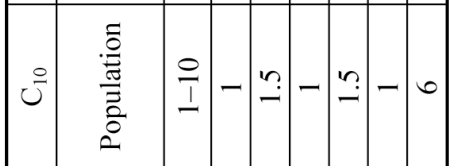

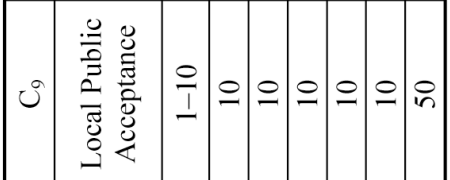

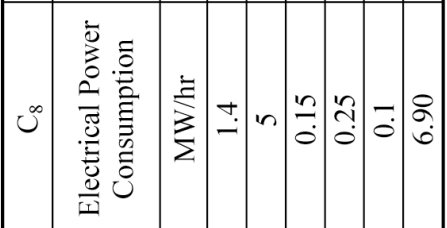

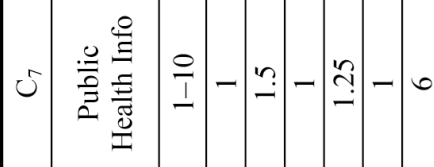

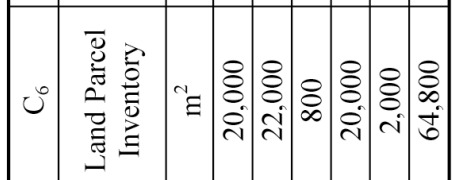

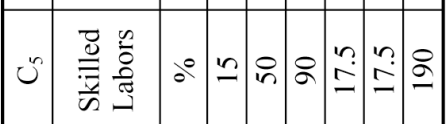

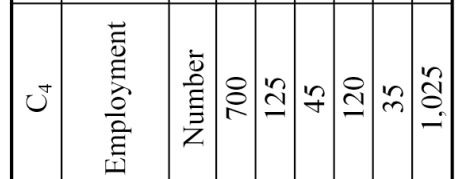

कิ

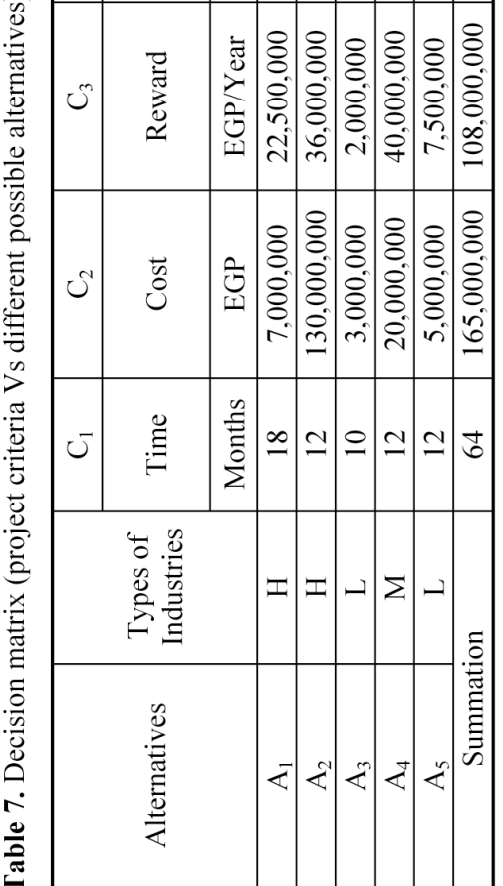

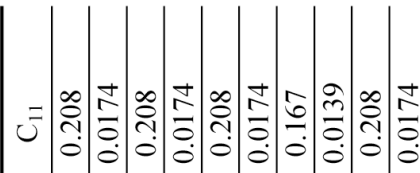

ن

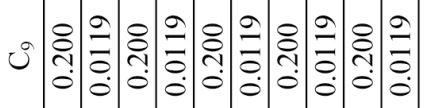

ن

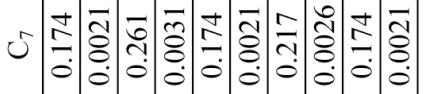

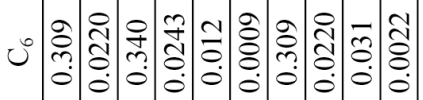

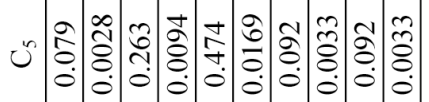

U

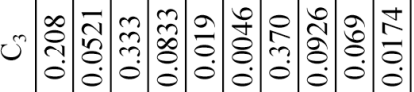

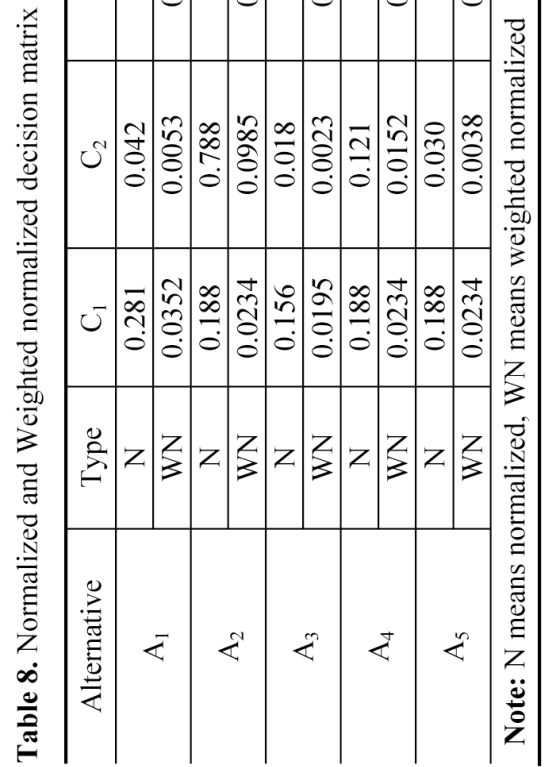

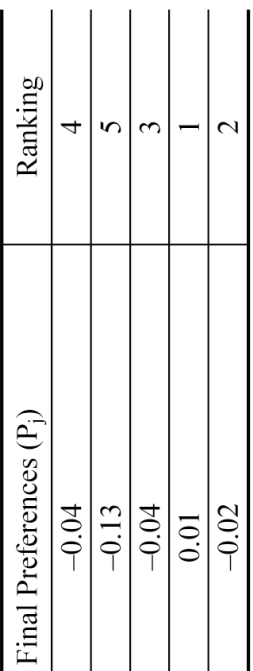

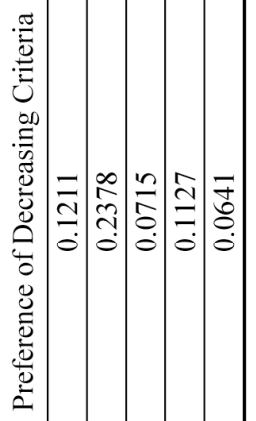

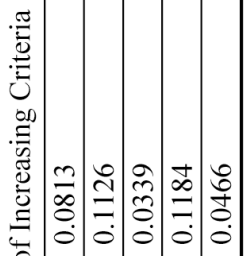

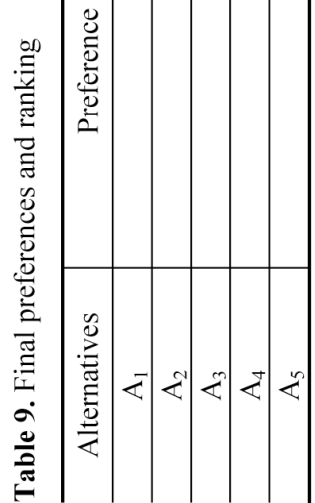


Thirdly, the normalized figures are multiplied by the weights of criteria forming weighted normalized matrix (see Table 8). By applying the Weighted-Sum Model (WSM) method on the values of Table 8, the final preferences and ranking of alternatives are obtained. It should be noted that some criteria are more preferred when their values increase (such as; Reward) while others are more preferred when their values decrease (such as; Time). What has been applied in this step in order to respect the nature of increasing and decreasing criteria is that, for each alternative, the summation of the increasing criteria preferences have been calculated separate from the summation of the decreasing criteria preferences. Then, the difference (net) between the two summations is considered the final preferences of alternatives as listed in Table 9.

By referring to Table 9, it can be noted that there are two alternatives $A_{3}$ and $A_{1}$ have the same final preference $(-0.04)$. Alternative $A_{3}$ is preferred than alternative $A_{1}$ because originally alternative $A_{3}$ carries slightly larger final preference (lesser negative value); however, the final preferences presented here are only up to two decimal places to facilitate the visual comparison between the different alternatives. It is now clear that the most appropriate (preferred) alternative out of the five selected industrial projects is the fourth alternative $\mathrm{A}_{4}$, a Medium type industry. It is the factory which produces and galvanizes steel towers of mobile phone networks.

\section{Sensitivity analysis}

Several efforts have been made to study the sensitivity of the criteria governing the decision making process (Mostafavi, Karamouz 2010; Zhang et al. 2008; Triantaphyllou, Sánchez 1997). The conducted sensitivity analysis reveals the most critical criterion and the most critical measure of performance that might affect the decision making process. The most critical criterion will be introduced first. It is previously mentioned that the Reward criterion is the most important one. The most critical criterion is not necessarily to be the most important criterion, in other words, not necessarily correspond to the highest weight. What is meant by the term "Critical" here is the smallest change that might occur to a certain criterion in order to affect the ranking of alternatives. Monitoring the behavior of alternatives is essential for the purpose of analysis. This can happen by observing the changes that occur in weights of criteria and its effect on the ranking of alternatives, considering two different points of views. The first one is for those who are concerned with the change within any two alternatives to reverse their existing ranking. However, it is also possible that others might be interested in only the best (top) alternative changes. As such, there are four definitions that can be considered; Absolute Any (AA), Absolute Top (AT), Percent Any (PA), and Percent Top (PT) (Mostafavi, Karamouz 2010; Zhang et al. 2008; Triantaphyllou, Sánchez 1997).

\subsection{Processing most critical criterion - absolute terms}

Table 10 shows all possible absolute changes in weights of criteria by applying Equations 1 or 2 . Where $\delta_{k, i, j}$ de- notes the minimum change in the current weight $W_{k}$ of Criterion $C_{k}$ such that the ranking of alternatives $\mathrm{A}_{i}$ and $\mathrm{A}_{j}$ will be reversed or become just equal:

$$
\begin{gathered}
\delta_{k, i, j}<\frac{\left(P_{j}-P_{i}\right)}{\left(a_{j k}-a_{i k}\right)}, \text { if }\left(a_{j k}>a_{i k}\right), \text { or } \\
\delta_{k, i, j}>\frac{\left(P_{j}-P_{i}\right)}{\left(a_{j k}-a_{i k}\right)}, \text { if }\left(a_{j k}<a_{i k}\right) .
\end{gathered}
$$

Such that " $p$ " is the final preference of alternatives and " $a$ " is a measure in the decision matrix of a specified criterion and corresponding to a specified alternative. For example $\delta_{1,1,2}$ can be calculated, using Tables 8 and 9 , as follows:

$$
\delta_{1,1,2}=\frac{(-0.13-(-0.04))}{(0.188-0.281)}=0.906 \approx 0.91 .
$$

The cells marked with N/A in the table indicate infeasible values. By looking for the smallest absolute value of $\delta_{k, i, j}$ throughout the entire table, it can be found that it is equal to $(-0.003)$. This means that Employment is the Absolute Any (AA) most critical criterion. It is important to recall that according to the weights of criteria, Reward was the most important criterion and not Employment; however, in this scenario, Reward wasn't the most critical criterion. By looking for the smallest absolute value of $\delta_{k, i, j}$ in all rows which are related to the best alternative only (Alternative $\mathrm{A}_{4}$ ), it can be found that $(0.08)$ is that value. Reward is the corresponding criterion to the value this value. This means that Reward is the Absolute Top (AT) most critical criterion.

It can be noticed that the entire column of criterion Local Public Acceptance does not carry any values. This means that the criterion Local Public Acceptance is "equally sensitive" to all alternatives. In fact, it not necessarily that all alternatives have the same value in regard of a certain criterion. It is a coincidence in this scenario that all alternatives had the same value towards the Local Public Acceptance criterion.

\subsection{Processing most critical criterion - relative terms}

Processing the most critical criterion in relative terms is based on Table 10. By applying Eq. (3), Table 11 is derived. Where $\delta_{k, i, j}$ denotes the minimum relative change in the current weight $W_{k}$ of criterion $C_{k}$ such that the ranking of alternatives $\mathrm{A}_{i}$ and $\mathrm{A}_{j}$ will be reversed or become just equal:

$$
\delta_{k, i, j}=\delta_{k, i, j} \times 100 / W_{k} .
$$

For example $\delta_{1,1,2}$ can be calculated, using $W_{k}$ from Table 5, as follows:

$$
\delta_{1,1,2}=0.91 \times 100 / 0.125=728 .
$$

Similarly, the cells marked with N/A in the table indicate infeasible values. By looking for the smallest relative value of $\delta_{i, j, k}$ throughout the entire table, it can be found that $(|-4.4|)$ is that value. Reward is the corresponding criterion to the value $(|-4.4|)$. This means that Reward is the Percent Any (PA) most critical criterion. 
Table 10. All possible $\delta_{k, i, j}$ values (absolute change in criteria weights)

\begin{tabular}{c|c|c|c|c|c|c|c|c|c|c|c}
\hline Pair of Alternatives & $\mathrm{C}_{1}$ & $\mathrm{C}_{2}$ & $\mathrm{C}_{3}$ & $\mathrm{C}_{4}$ & $\mathrm{C}_{5}$ & $\mathrm{C}_{6}$ & $\mathrm{C}_{7}$ & $\mathrm{C}_{8}$ & $\mathrm{C}_{9}$ & $\mathrm{C}_{10}$ & $\mathrm{C}_{11}$ \\
\hline $\mathrm{A}_{1}-\mathrm{A}_{2}$ & 0.911 & -0.115 & -0.683 & 0.152 & N/A & N/A & N/A & N/A & N/A & -1.025 & N/A \\
\hline $\mathrm{A}_{1}-\mathrm{A}_{3}$ & -0.017 & -0.087 & -0.011 & $\mathbf{0 . 0 0 3}$ & 0.005 & -0.007 & N/A & -0.012 & N/A & N/A & N/A \\
\hline $\mathrm{A}_{1}-\mathrm{A}_{4}$ & N/A & 0.577 & N/A & N/A & 3.453 & N/A & 1.045 & N/A & N/A & 0.545 & -1.091 \\
\hline $\mathrm{A}_{1}-\mathrm{A}_{5}$ & N/A & N/A & -0.161 & N/A & 1.695 & N/A & N/A & N/A & N/A & N/A & N/A \\
\hline $\mathrm{A}_{2}-\mathrm{A}_{3}$ & N/A & -0.114 & -0.278 & N/A & 0.416 & N/A & N/A & N/A & N/A & N/A & N/A \\
\hline $\mathrm{A}_{2}-\mathrm{A}_{4}$ & N/A & N/A & N/A & N/A & N/A & N/A & N/A & N/A & N/A & N/A & -3.140 \\
\hline $\mathrm{A}_{2}-\mathrm{A}_{5}$ & N/A & N/A & -0.408 & N/A & N/A & N/A & N/A & N/A & N/A & N/A & N/A \\
\hline $\mathrm{A}_{3}-\mathrm{A}_{4}$ & 1.387 & 0.421 & 0.123 & 0.592 & N/A & 0.146 & 0.997 & 2.990 & N/A & 0.520 & -1.040 \\
\hline $\mathrm{A}_{3}-\mathrm{A}_{5}$ & 0.646 & 1.666 & N/A & N/A & N/A & 1.090 & N/A & N/A & N/A & N/A & N/A \\
\hline $\mathrm{A}_{4}-\mathrm{A}_{5}$ & N/A & 0.255 & $\mathbf{0 . 0 7 7}$ & 0.279 & N/A & 0.083 & 0.532 & 1.064 & N/A & 0.278 & -0.555 \\
\hline & & & & & & &
\end{tabular}

Table 11. All possible $\delta_{k, i, j}$ values (relative change in criteria weights)

\begin{tabular}{c|c|c|c|c|c|c|c|c|c|c|c}
\hline Pair of Alternatives & $\mathrm{C}_{1}$ & $\mathrm{C}_{2}$ & $\mathrm{C}_{3}$ & $\mathrm{C}_{4}$ & $\mathrm{C}_{5}$ & $\mathrm{C}_{6}$ & $\mathrm{C}_{7}$ & $\mathrm{C}_{8}$ & $\mathrm{C}_{9}$ & $\mathrm{C}_{10}$ & $\mathrm{C}_{11}$ \\
\hline $\mathrm{A}_{1}-\mathrm{A}_{2}$ & 728.8 & -91.7 & -273.3 & 639.5 & N/A & N/A & N/A & N/A & N/A & -614.9 & N/A \\
\hline $\mathrm{A}_{1}-\mathrm{A}_{3}$ & -13.5 & -69.6 & $\mathbf{- 4 . 4}$ & -13.9 & 15.0 & -10.0 & N/A & -24.5 & N/A & N/A & N/A \\
\hline $\mathrm{A}_{1}-\mathrm{A}_{4}$ & N/A & 461.4 & N/A & N/A & 9669.7 & N/A & 8779.0 & N/A & N/A & 327.2 & -1308.7 \\
\hline $\mathrm{A}_{1}-\mathrm{A}_{5}$ & N/A & N/A & -64.2 & N/A & 4745.8 & N/A & N/A & N/A & N/A & N/A & N/A \\
\hline $\mathrm{A}_{2}-\mathrm{A}_{3}$ & N/A & -91.0 & -111.2 & N/A & 1164.0 & N/A & N/A & N/A & N/A & N/A & N/A \\
\hline $\mathrm{A}_{2}-\mathrm{A}_{4}$ & N/A & N/A & N/A & N/A & N/A & N/A & N/A & N/A & N/A & N/A & -3768.4 \\
\hline $\mathrm{A}_{2}-\mathrm{A}_{5}$ & N/A & N/A & -163.3 & N/A & N/A & N/A & N/A & N/A & N/A & N/A & N/A \\
\hline $\mathrm{A}_{3}-\mathrm{A}_{4}$ & 1109.3 & 336.5 & 49.3 & 2487.2 & N/A & 204.7 & 8371.5 & 6278.6 & N/A & 312.0 & -1247.9 \\
\hline $\mathrm{A}_{3}-\mathrm{A}_{5}$ & 516.9 & 1332.7 & N/A & N/A & N/A & 1526.6 & N/A & N/A & N/A & N/A & N/A \\
\hline $\mathrm{A}_{4}-\mathrm{A}_{5}$ & N/A & 203.6 & $\mathbf{3 0 . 8}$ & 1171.9 & N/A & 116.6 & 4470.3 & 2235.2 & N/A & 166.6 & -666.4 \\
\hline
\end{tabular}

By looking for the smallest relative value of $\delta_{i, j, k}$ in all rows which are related to the best alternative only (Alternative $\mathrm{A}_{4}$ ), it can be found that (30.8) is that value. Reward is the corresponding criterion to the value (30.8). This means that Reward is also the Percent Top (PT) most critical criterion.

Table 12. Criticality and sensitivity values

\begin{tabular}{c|c|c}
\hline Code & Criticality Degree & Sensitivity Value \\
\hline $\mathrm{C}_{1}$ & -13.5 & 0.074 \\
\hline $\mathrm{C}_{2}$ & -69.6 & 0.014 \\
\hline $\mathrm{C}_{3}$ & -4.4 & 0.227 \\
\hline $\mathrm{C}_{4}$ & -13.9 & 0.072 \\
\hline $\mathrm{C}_{5}$ & 15.0 & 0.067 \\
\hline $\mathrm{C}_{6}$ & -10.0 & 0.100 \\
\hline $\mathrm{C}_{7}$ & 4470.3 & 0.0002 \\
\hline $\mathrm{C}_{8}$ & -24.5 & 0.041 \\
\hline $\mathrm{C}_{9}$ & $\mathrm{~N} / \mathrm{A}$ & $\mathrm{N} / \mathrm{A}$ \\
\hline $\mathrm{C}_{10}$ & 166.6 & 0.006 \\
\hline $\mathrm{C}_{11}$ & -666.4 & 0.002 \\
\hline
\end{tabular}

\subsection{Criticality degrees and sensitivity coefficients}

As for the criticality degrees of criteria (see Table 12), they can be calculated by choosing the smallest value on each column of Table 11. By calculating the reciprocal of the absolute values of "Criticality Degrees", the sensitivity coefficients of the criteria can be achieved as per Table 12. The ranking of the criteria from the most sensitive to the least sensitive will be as follows: 1) Reward; 2) Land Parcel Inventory; 3) Employment; 4) Time; 5) Skilled Labors; 6) Electrical Power Consumption;
7) Cost; 8) Pollution; 9) Waste Management Impact; 10) Public Health Info.

\subsection{Most critical measure of performance}

The second stage of the sensitivity analysis is determining the most critical measure of performance. In other words, figuring out which specific value of the gathered criteria is the most critical. The methodology used here is Trial and Error. A solution has been developed using Microsoft Visual Basic $6.5^{\circledR}$ in order to get the final measures of performance needed so that the ranking of alternatives $A_{i}$ and $A_{k}$ will be reversed or become just equal. Table 13 shows all possible absolute measures of performance developed through Microsoft Visual Basic $6.5^{\circledR}$. Table 14 shows all relative measures of performance $(\%)$ developed through the program. The relative measures are all relative to the first alternative $\left(\mathrm{A}_{i}\right)$ to the left of the "Pair of Alternatives" column. The negative signs (-ve) in cells of Table 14 means that the original measure of performance of alternative $A_{i}$ needs to be decreased "to" the cell's current percent value (not to be decrease " $b y$ " the cell's percent value) in order to let the final preference of the two alternatives $\mathrm{A}_{i}$ and $\mathrm{A}_{j}$ be reversed or become almost equal.

The most critical measure of performance can be achieved by comparing the smallest positive value in Table 14 (the relative measures), with the highest negative value. Then, select the value which is closest to the number $(100 \%)$. In other words, if the smallest positive value equals to $105 \%$ and the highest negative value equals to $-90 \%$. Then the $105 \%$ will be more critical since it means that the original corresponding measure 
Table 13. All possible absolute critical measures of performance

\begin{tabular}{|c|c|c|c|c|c|c|c|c|c|c|c|}
\hline $\begin{array}{l}\text { Pair of Alternatives } \\
\qquad \mathrm{A}_{i}-\mathrm{A}_{j}\end{array}$ & $\mathrm{C}_{1}$ & $\mathrm{C}_{2}$ & $\mathrm{C}_{3}$ & $\mathrm{C}_{4}$ & $\mathrm{C}_{5}$ & $\mathrm{C}_{6}$ & $\mathrm{C}_{7}$ & $\mathrm{C}_{8}$ & $\mathrm{C}_{9}$ & $\mathrm{C}_{10}$ & $\mathrm{C}_{11}$ \\
\hline $\mathrm{A}_{1}-\mathrm{A}_{2}$ & $\mathrm{~N} / \mathrm{A}$ & $120,000,000$ & $\mathrm{~N} / \mathrm{A}$ & $\mathrm{N} / \mathrm{A}$ & N/A & N/A & N/A & N/A & N/A & 6.4 & $\mathrm{~N} / \mathrm{A}$ \\
\hline$A_{1}-A_{3}$ & N/A & N/A & $25,000,000$ & N/A & 2.0 & N/A & N/A & 0.4 & N/A & N/A & N/A \\
\hline$A_{1}-A_{4}$ & N/A & N/A & $45,000,000$ & $\mathrm{~N} / \mathrm{A}$ & N/A & N/A & $\mathrm{N} / \mathrm{A}$ & N/A & $\mathrm{N} / \mathrm{A}$ & N/A & $\mathrm{N} / \mathrm{A}$ \\
\hline$A_{1}-A_{5}$ & N/A & $\mathrm{N} / \mathrm{A}$ & $\mathrm{N} / \mathrm{A}$ & N/A & N/A & $\mathrm{N} / \mathrm{A}$ & $\mathrm{N} / \mathrm{A}$ & $\mathrm{N} / \mathrm{A}$ & N/A & N/A & $\mathrm{N} / \mathrm{A}$ \\
\hline$A_{2}-A_{3}$ & $\mathrm{~N} / \mathrm{A}$ & $\mathrm{N} / \mathrm{A}$ & $150,000,000$ & N/A & N/A & $\mathrm{N} / \mathrm{A}$ & $\mathrm{N} / \mathrm{A}$ & $\mathrm{N} / \mathrm{A}$ & N/A & N/A & N/A \\
\hline $\mathrm{A}_{2}-\mathrm{A}_{4}$ & N/A & N/A & $150,000,000$ & N/A & N/A & $\mathrm{N} / \mathrm{A}$ & N/A & N/A & N/A & N/A & N/A \\
\hline$A_{2}-A_{5}$ & N/A & N/A & $190,000,000$ & N/A & N/A & $\mathrm{N} / \mathrm{A}$ & N/A & N/A & N/A & N/A & $\mathrm{N} / \mathrm{A}$ \\
\hline $\mathrm{A}_{3}-\mathrm{A}_{4}$ & N/A & N/A & $20,000,000$ & N/A & N/A & N/A & N/A & N/A & N/A & N/A & N/A \\
\hline$A_{3}-A_{5}$ & N/A & N/A & $15,000,000$ & $\mathrm{~N} / \mathrm{A}$ & N/A & N/A & N/A & N/A & N/A & N/A & $\mathrm{N} / \mathrm{A}$ \\
\hline $\mathrm{A}_{4}-\mathrm{A}_{5}$ & 27.4 & $70,000,000$ & N/A & N/A & N/A & N/A & N/A & 7.3 & N/A & 2.6 & $\mathrm{~N} / \mathrm{A}$ \\
\hline
\end{tabular}

Table 14. All possible relative critical measures of performance

\begin{tabular}{|c|c|c|c|c|c|c|c|c|c|c|c|}
\hline $\begin{array}{l}\text { Pair of Alternatives } \\
\qquad \mathrm{A}_{i}-\mathrm{A}_{j}\end{array}$ & $\mathrm{C}_{1}$ & $\mathrm{C}_{2}$ & $\mathrm{C}_{3}$ & $\mathrm{C}_{4}$ & $\mathrm{C}_{5}$ & $\mathrm{C}_{6}$ & $\mathrm{C}_{7}$ & $\mathrm{C}_{8}$ & $\mathrm{C}_{9}$ & $\mathrm{C}_{10}$ & $\mathrm{C}_{11}$ \\
\hline $\mathrm{A}_{1}-\mathrm{A}_{2}$ & N/A & 1714.23 & $\mathrm{~N} / \mathrm{A}$ & $\mathrm{N} / \mathrm{A}$ & N/A & $\mathrm{N} / \mathrm{A}$ & $\mathrm{N} / \mathrm{A}$ & N/A & $\mathrm{N} / \mathrm{A}$ & 640 & N/A \\
\hline$A_{1}-A_{3}$ & N/A & N/A & 111.11 & N/A & -13.3 & -8.95 & $\mathrm{~N} / \mathrm{A}$ & -28.57 & $\mathrm{~N} / \mathrm{A}$ & $\mathrm{N} / \mathrm{A}$ & N/A \\
\hline$A_{1}-A_{4}$ & N/A & N/A & 200 & N/A & N/A & N/A & $\mathrm{N} / \mathrm{A}$ & N/A & $\mathrm{N} / \mathrm{A}$ & N/A & N/A \\
\hline$A_{1}-A_{5}$ & N/A & N/A & N/A & N/A & $\mathrm{N} / \mathrm{A}$ & $\mathrm{N} / \mathrm{A}$ & N/A & N/A & $\mathrm{N} / \mathrm{A}$ & $\mathrm{N} / \mathrm{A}$ & $\mathrm{N} / \mathrm{A}$ \\
\hline $\mathrm{A}_{2}-\mathrm{A}_{3}$ & N/A & N/A & 416.67 & N/A & $\mathrm{N} / \mathrm{A}$ & $\mathrm{N} / \mathrm{A}$ & $\mathrm{N} / \mathrm{A}$ & $\mathrm{N} / \mathrm{A}$ & $\mathrm{N} / \mathrm{A}$ & N/A & N/A \\
\hline $\mathrm{A}_{2}-\mathrm{A}_{4}$ & N/A & N/A & 416.67 & N/A & $\mathrm{N} / \mathrm{A}$ & $\mathrm{N} / \mathrm{A}$ & $\mathrm{N} / \mathrm{A}$ & $\mathrm{N} / \mathrm{A}$ & $\mathrm{N} / \mathrm{A}$ & $\mathrm{N} / \mathrm{A}$ & N/A \\
\hline $\mathrm{A}_{2}-\mathrm{A}_{5}$ & N/A & N/A & 527.78 & N/A & N/A & $\mathrm{N} / \mathrm{A}$ & N/A & N/A & N/A & $\mathrm{N} / \mathrm{A}$ & N/A \\
\hline $\mathrm{A}_{3}-\mathrm{A}_{4}$ & N/A & N/A & 1000 & N/A & $\mathrm{N} / \mathrm{A}$ & N/A & $\mathrm{N} / \mathrm{A}$ & $\mathrm{N} / \mathrm{A}$ & $\mathrm{N} / \mathrm{A}$ & N/A & N/A \\
\hline $\mathrm{A}_{3}-\mathrm{A}_{5}$ & $\mathrm{~N} / \mathrm{A}$ & N/A & 750 & N/A & $\mathrm{N} / \mathrm{A}$ & $\mathrm{N} / \mathrm{A}$ & $\mathrm{N} / \mathrm{A}$ & N/A & $\mathrm{N} / \mathrm{A}$ & $\mathrm{N} / \mathrm{A}$ & N/A \\
\hline $\mathrm{A}_{4}-\mathrm{A}_{5}$ & 228.3 & 350 & $\mathrm{~N} / \mathrm{A}$ & N/A & N/A & 365.35 & $\mathrm{~N} / \mathrm{A}$ & 2920 & $\mathrm{~N} / \mathrm{A}$ & 173.3 & $\mathrm{~N} / \mathrm{A}$ \\
\hline Overall Criticality & 228.3 & 350 & 111.11 & $\mathrm{~N} / \mathrm{A}$ & -13.3 & -8.95 & $\mathrm{~N} / \mathrm{A}$ & -28.57 & N/A & 173.3 & N/A \\
\hline
\end{tabular}

needs to be increased by only $5 \%$ in order to change the ranking of alternatives; however, the original measure corresponding to the $-90 \%$ needs to be decreased by $10 \%$ to do the same effect. Absolute values (listed in Table 14) are not applicable in this case since measures corresponding to each criterion have different units. There is no unite platform on which the absolute values can be compared together; however, relative figures are altogether connected to the percentage platform. Similar as previous analysis, there will be Percent Any and Percent Top values. The Percent Top value equals to $(200 \%)$ and Percent Any value equals to (111.11\%). Both values correspond to criterion $\mathrm{C}_{3}$. The table cells (in both Tables 13 and 14) marked with $\mathrm{N} / \mathrm{A}$, indicating that the program did not find any solutions throughout the given range.

\section{Conclusions}

This paper introduced an approach for selecting industrial projects using Multi-Criteria Decision Making (MCDM) techniques. In view of the fact that some mega projects are found not to be successful just before construction, during construction or even realize after the early stages of operation. MCDM can be applied during the feasibility study phase prior to design, procurement and construction stages to have the best use of its results and avoid the possible losses. The feasibility study needs to answer the question: "Does the idea make economic sense?" Further technically detailed considerations such as production lines of factories and machinery can be discussed from the Industrial Engineering perspective. This approach is developed in order to aid the private investors (foreign or local) who have investment intentions in Egypt. It aids them to select the most suitable/preferred industrial project to be constructed in Egypt's industrial zones in order to invest their capitals.

The formulation/development of this approach has passed through several stages. It starts with gathering the necessary factors from interviews and references, then getting the importance of each factor. Afterwards, necessary screening is performed to eliminate the low important factors. Giving relative importance and performing final refinement before proceeding are also important stages in the approach formulation. Weights of the remained factors have been indicated using Simos' procedure. Then after real values of factors have been collected from five case studies of industrial projects, a vital decision matrix have been prepared on which the ranking of the five case studies (alternatives) has took place. The ranking has taken place using Weighted-Sum Model method (WSM). Necessary sensitivity analysis has been performed to figure out the most critical criterion and the most critical measure of performance of this decision making approach. Also, it has been proven that the criterion which carries the highest weight is not necessarily be the criterion which can change the ranking of alternatives if subjected to the slightest change in its weight, i.e., it has 
been proven that the most important criterion does not necessarily be the most critical criterion.

The paper proposed a methodology for selecting industrial projects in Egypt. To achieve this main objective, the following sub-objectives are achieved: 1) A shortlist/key-list containing the most important factors that the decision maker (private investor) should consider is created; 2) A Methodology that can reach a solution to the most suitable industrial project to be constructed in Egypt; 3) Application of sensitivity analysis for better understanding.

\section{References}

Amer, O. M. 2010. A multi-criteria decision making approach for selecting industrial projects. MSc Thesis. Construction Engineering and Management Division, Structural Engineering Department, Faculty of Engineering, Cairo University, Egypt.

Changshan, W. 2007. Remote sensing applications in urban socioeconomic analysis, in V. Mesev (Ed.). Integration of GIS and Remote Sensing. John Wiley \& Sons, Inc., NY, US, 149-172.

Dozzi, S. P.; AbouRizk, S. M.; Schroeder, S. L. 1996. Utilitytheory model for bid markup decisions, Journal of Construction Engineering and Management ASCE 122(2): 119-124. http://dx.doi.org/10.1061/(ASCE)07339364 (1996)122:2(119)

Figueira, J.; Roy, B. 2002. Determining the weights of criteria in the ELECTRE type methods with a revised Simos' procedure, European Journal of Operational Research 139(1-2): 317-326. http://dx.doi.org/10.1016/S03772217(01)00370-8

Fishburn, P. C. 1967. Additive utilities with incomplete product sets: application to priorities and assignments, Operations Research 15: 537-542. http://dx.doi.org/10.1287/opre.15.3.537

Marzouk, M.; Moselhi, O. 2003. A decision support tool for construction bidding, Construction Innovation: Information, Process, Management 3(2): 111-124.
Marzouk, M. 2008a. SIR-VE: A generic tool for value engineering, in Proc. of the $5^{\text {th }}$ International Engineering and Construction Conference (IECC'5), 27-29 August, 2008. Irvine, California, USA, 663-672.

Marzouk, M. 2008b. A superiority and inferiority ranking model for contractor selection, Construction Innovation: Information, Process, Management 8(4): 250-268.

Mostafavi, A.; Karamouz, M. 2010. Selecting appropriate project delivery system: a fuzzy approach with risk analysis, Journal of Construction Engineering and Management ASCE 136(8): 923-930.

http://dx.doi.org/10.1061/(ASCE)CO.1943-7862.0000190

Roussat, N.; Dujet, C.; Méhu, J. 2009. Choosing a sustainable demolition waste management strategy using multicriteria decision analysis, Waste Management 29(1): 12-20. http://dx.doi.org/10.1016/j.wasman.2008.04.010

Tam, C. M.; Tong, T. K. L.; Wong, Y. W. 2004. Selection of concrete pump using the superiority and inferiority ranking method, Journal of Construction Engineering and Management ASCE 130(6): 827-834. http://dx.doi.org/10.1061/(ASCE)0733-9364(2004)130: 6(827)

Triantaphyllou, E.; Sánchez, A. 1997. A sensitivity analysis approach for some deterministic multi-criteria decision making methods, Decision Sciences 28(1): 151-194. http://dx.doi.org/10.1111/j.1540-5915.1997.tb01306.x

Ulubeyli, S.; Kazaz, A. 2009. A multiple criteria decision making approach to the selection of concrete pumps, Journal of Civil Engineering and Management 15(4): 369-376. http://dx.doi.org/10.3846/1392-3730.2009.15.369-376

UNDP. 2010. Fighting climate change: human solidarity in a divided world. The 2007/2008 Human Development Report. United Nations Development Programme [cited 10 April 2010]. Available from Internet: http://hdr.undp.org/ en/media/HDR_20072008_EN_Complete.pdf

Zhang, C.; Zayed, T.; Hammad, A. 2008. Resource management of bridge deck rehabilitation: Jacques Cartier bridge case study, Journal of Construction Engineering and Management ASCE 134(5): 311-319. http://dx.doi.org/ 10.1061/(ASCE)0733-9364(2008)134:5(311)

Mohamed MARZOUK. Associate Professor at Department of Structural Engineering, Faculty of Engineering, Cairo University. He received his BSc and MSc in Civil Engineering from Cairo University in 1995 and 1997, respectively. He received his $\mathrm{PhD}$ form Concordia University in 2002. He is Certified Project Management Professional (PMP®) and Certified Project Management Consultant (Egyptian Syndicate of Engineers). His research interests includes simulation and optimization of construction processes, O-O simulation, fuzzy logic and its applications in construction, risk analysis, and decision analysis.

Omar AMER. He is currently a Projects Engineer at MCG Misr Consult Group, Cairo, Egypt. In 2005, he joined a research team at University of Maryland, MD, USA, for a short-term period. He received his BSc in Construction and Building Engineering from the Arab Academy for Science \& Technology and Maritime Transport in 2006. He received his MSc in Structural Engineering from Cairo University in 2010. His research interests includes risk assessment, geo-risk management, multi-criteria decision making, construction management and geotechnical engineering.

Moheeb EL-SAID. Professor of construction engineering and management at Department of Structural Engineering, Faculty of Engineering, Cairo University. His research interests includes productivity, schedule risk assessment, life cycle costs, and simulation. 